\title{
MEDIATION ON INDUSTRIAL RELATION DISPUTE AND ITS RELATION WITH RELATIVE AUTHORITY IN THE LEGAL PROCEEDINGS PROCESS
}

\author{
Iron Sarira \\ Business Law Department, Faculty of Humanities, Bina Nusantara University \\ Jl. KemanggisanIlir III no. 45, Kemanggisan, Palmerah, Jakarta Barat, 11480 \\ irons@binus.edu
}

\begin{abstract}
Industrial Relations or Employment in the Indonesia legal system is based on Law No 13 of 2003 on Employment, and the Law No 2 of 2004 concerning Industrial Relations Dispute Settlement. The industrial relations are expected to be harmonious and give positive mutual engagement in the effort to support the development of Indonesian society and to improve the welfare of the Indonesian people, especially the workers or the labors. The desired goal is still far from the expectations if seeing the practice of industrial relations. The aim of the research was to get a better understanding of the practice and theory following the laws which regulated the procedures of employment as well as technical aspects. The research method applied was library research. There was some positive law approaches related to this research, which consisted of several rules as the normative law, such as Law No 2 of 2004, Act Number 30 of 1999, and PERMA No 1 of 2008. The research finds that the dispute of industrial relations as mentioned in Article 4 PERMA No 1 of 2008, Article 8 of Law No 2 of 2004, and Article 136 paragraph (2) of Act 13 of 2003. It explains and requires the mediation process before going into the courts of first instance (in this case is the Industrial Relations Court). The mediation process is led by a mediator who has the authority to conduct industrial relations dispute resolution processes in their jurisdiction. Industrial relations mediator does not have the authority to process the industrial relations dispute if the case territory is not located within its jurisdiction. As for, the relative authority of this provide an understanding that mediator aims to resolve disputes in industrial relations must apply the principle of locus delictus as a manifestation of its authority under the jurisdiction of the law.
\end{abstract}

Keywords: industrial relation dispute, mediation, relative authority, legal proceeding process.

\section{INTRODUCTION}

Conflictor dispute often is the case that arises in the life of the human as a social being or zoon politicon (Soeroso, 2006). The dispute that gave rise to conflict can occur in various sectors of life and public relationship. In relationship or interaction, humans become the subject of legal (person) or in the case of humans function in carrying out legal acts by acting on behalf of a legal entity or recht person (Sari, Kartika, \& Simanunsong, 2007). Nugroho \& Susanti (2010) stated that conflict as a term use in the field of political, social, and economic while the dispute is synonymous with the legal aspect.

Disputes in the law (legal disputes) can be categorized in the completion of the proceedings in litigation or proceedings in the General Court (State Court, High Court, and Supreme Court) or the other court such as the Administrative Court, the Religious Courts, and Military Courts. The outside of the general court which is called Alternative Disputes Resolution (ADR) and known in some ways like Consultation, Negotiation, Mediation/Conciliation, Arbitration, Opinion The Expert/Expert, Jurisprudence. Proceedings in both aspects of the process as mentioned above has a difference. 
Litigation or legal proceedings in General courts had the more permanent legal force with the condition of no appeal and/or cassation to the Supreme Court but resulted in agreement that is adversarial which is unable to embrace the common interest. So, it tends to cause new problems, more time-consuming process, and a long and large cost of the process, unresponsive and cause enmity between disputing parties. Although this method is more dominant in every case of dispute settlement, by the development and plurality of ideas and advances understanding of the society today, especially in Indonesia, then the alternative disputes resolution begin to be excellent in the 21st century, particularly with the release of PERMA No. 1 of 2008. Through the process outside of the court, it produces an agreement of a win-win solution, the confidentiality guarantee of disputes' parties, the avoidance of delay caused by administrative and procedural matters, the problem resolved in a comprehensive manner of togetherness, and the maintenance of a good relationship.

Alternative Disputes Resolution (ADR) as an alternative dispute resolution has since long been recognized in various beliefs and cultures in an effort to resolve the dispute in the community. The differences are in the approach and the method that are adjustable with the local legal culture (Friedman, 1984). For example, Chinese people tend to be reluctant to solve their dispute before the court, because of a harmonious relationship (Chang as cited in Nugroho \& Susanti Adi, 2010). Their leading figures become the mediator in the disputes that arise. Japanese society has a culture concialitory culture where mediation or conciliation has long been recognized as a suitable mechanism for resolving disputes, not litigation (Sato as cited in Nugroho \& Susanti Adi, 2010).

Nowadays, the industrialization era brings a wide range of phenomena, primarily for the parties involved in industrial relations which employers, workers, and government. The phenomenon raises feeling is not easy to realize how industrial relations are harmonious, dynamic, and fair. This happens because in the era of industrialization characterized by advances in science and technology and industrial relations problems become increasingly complex.

A few examples of the causes of industrial disputes are the issue of termination of employment (PHK). The rights issues that have been assigned or about the employment situation have not been established in employment contracts, company regulations, collective agreements, and legislation. Various labor problems can also arise because there is no guarantee of the basic and normative rights of the workers as well as discrimination in the workplace. Thus, it will cause conflict and usually end with the termination of employment. Associated with the termination, the labor becomes the weaker side when faced with an employer who is a party that is more powerful or have more power.

The phenomenon of industrial relations disputes in various places should not be allowed to drag on because in turn will obstruct the realization of manpower development as an integral part of national development. Based on Pancasila and the Constitution of the Republic of Indonesia 1945, the national development carried out in the framework of the development of Indonesian society fully to enhance the dignity, status, and pride of labor and to realize a society that prosperous, just, wealthy, and equitable both in materially and spiritually.

Laws on the settlement of disputes relating to industrial relations (PHI), which is implemented under Law No 22 of 1957 on the Settlement of Labour Disputes and LawNo 12 of 1964 on Termination of Employment in Private Companies, has been declared null and void. It because of no longer able to accommodate the development, especially regarding the rights of workers/laborers individually. Therefore, in the case rather than as part of a union/labor, workers/labors are given room to act alone in resolving industrial disputes, based on the application of theAct No 2 of 2004 concerning Industrial Relations Dispute Settlement, which had declared on January 14, 2004.

The provisions of Law No. 2/2004 arrange the settlement of labor disputes using two (2) ways, namely the settlement of disputes outside the courts and through the industrial relations court. 
Thus, settlement arrangements based on the passion of the settlement of disputes by discussion and consensus, thus the settlement put forward a win-win solution. By way of the settlement, the production process is expected to continue to run as usual. In conjunction with the settlement of industrial disputes outside of the court, then by Law No 2 of 2004, the process of the settlement is by the bipartite, mediation, conciliation and/or arbitration (Nugroho \& Susanti Adi, 2009). Harahap (2008) states that the dispute settlement through peace is felt much more effective and efficient. That is why lately various settlement methods develop outside the court as mentioned before.

Mediation as a means or method of dispute settlement outside the court began to get its own place and be the option for solving it. In the mediation process preferably reaching an agreement based on negotiation for consensus also has a substantial advantage and psychological, which is very different from the pattern of justice where it is referring to positive laws that govern and prevail. So that the achievement of the decision put forward the winning side and the losing side in the dispute, of course, also in addition to the other weaknesses when compared with the method of dispute resolution through mediation that emphasizes peace. Since the beginning of Article 130 HIR and Article 154 RBG are recognizing and requiring the settlement of disputes through peaceful. Based on the provisions of this article, it is undeniable that the system prefers settling disputes with peace rather than the usual decision process.

The system implementation concept of a win-win solution is more preferred than the application of winning or losing. Thus, the existence of Article 130 HIR (Herziene Indonesisch Regliment) put forward for the parties to resolve their own problems to reach an agreement without the intervention of a judge. Furthermore, the agreement takes the form of the peace requested the judge to put in the form of the deed of peace or dading (acte van dading). So it seems obvious to peace agreed by the litigants, the judge intervention is very small, only a certificate making peace imposed as a court judgment that contains punishment the parties to abide by and fulfill the contents of the peace.

The mediation is generally done outside the court. Industrial relations dispute is one example of the application of mediation outside the court. The dispute is made after the parties have not succeeded in the process of bipartite and continued by one of the parties to take the Tripartite process. The majority, dispute resolution processes of industrial relations at the Tripartite level passed by mediation. Harahap (2008) again states that it means the parties are choosing employees at the Office or Department of Manpower or where the employee and the parties are domiciled (actor sequitur forum rei or forum domicile) as an arbitrator or mediator. It also allows the parties choose independent conciliator or arbitrator that registered at the office.

In general, the attitude and behavior of judges, which are applying the Article $130 \mathrm{HIR}$, are merely a formality rather than dedication and moral appeal by the expression that says "intrinsic justice obtained by the disputing parties through peace" (Harahap \& M.Yahya, 2008). The judges should be empowered to resolve the matters with peace by implementing the concept of the win-win solution as outlined in Article 130 HIR through mediation integration mechanisms in the judicial system. This system has a formal foundation starting from the scope of the mediation integration, the pre-mediation stage, the mediation process, the strength of evidence in the mediation process, up to the place and the cost of mediation. The mediation process in the courts either public or an industrial relations court basically has similarities in the implementation process and provide benefits to both parties. Nonetheless, the disputing parties can make their choice, either by using an authoritative mediator or an independent mediator.

Each district court has limited jurisdiction regarding its position. This condition is by Article 4 paragraph (1) of Law No 2 of 1986, which states that the district court is located in Municipality, or the district has jurisdiction in those place. Under this article, the authority to hear district court is only limited in its jurisdiction, so there is no authority outside the jurisdiction. The position of the legal area determines the limit of the relative competence to judge for each district court. Although cases of 
disputed include the absolute jurisdiction of the general courts, the absolute authority is limited by the relative authority of the judge. This is consistent with the mediation process in the scope of industrial relations problems related to Article 8 of Law No 2 of 2004. It states the settlement of disputes through the mediation of industrial relations dispute is conducted by mediators at the Office or Department or related office responsible for labor affairs in the municipality or local district as having the relative authority in the resolution of the industrial relations dispute. It needs to be explained briefly under the provisions of Article 118 HIR (Article 142 RBG) and Article 99 Rv. It has some provisions as a benchmark in determining the relative competence which in this paper refers to the residence of the defendant known as Actor sequitur forum Rei or the scene (criminal) known as the locus delicti.

Related to the case outside the criminal case, which is the civil case, Article 118 paragraph (1) HIR has set a standard of relative competence of district court in prosecutes a case (in general are legal proceedings process within the scope of mediation). This case based on residence of defendant (civil cases) - actor sequitur forum rei, not to the locus delictus as applied to the criminal cases. Article 84 paragraph (1) Code of Criminal Procedure (KUHP) which explains the basis on the scene. So it is misleading to make the basis of the relative competence related to civil cases based on the scene of a case or the locus delictus.

The mediator can refuse mediation filed by the plaintiff on the basis that the area of the case is outside its authority under the Article 8 Law No 2 of 2004, which is the most specific rules (lex specialist) to things that have been mentioned above. This explains that the mediator in an area can refuse to provide mediation filed by the plaintiff if the case is not in the area of their mediation. Industrial relations dispute which resulted in the conflict over rights and/or conflict of interests over a position as core business with the expiry of employment contract status of the employment is considered null and void. This condition is because the unsuccessful bipartite process that should have the minutes of the results of negotiations.

This annulment by law is an interception against any recommendation by the mediator who does not have the relative authority to handle mediation filed by the plaintiff. So that the mediator has a recommendation which states that the mediator in a jurisdiction (Jakarta) does not have the authority to process further mediation related to the limits of relative authority that are not competent to complete the mediation process. So it is recommended to apply the mediation process at any other jurisdictions (South Tangerang) as the jurisdiction which has the authority in the mediation process on the basis of Article 8 of Law No. 2 of 2004. This matter is very common for the mediators in the Jakarta jurisdiction but actually contrary to what is stated in Article 84 paragraph (1) KUHAP and Article 118 paragraph(1) HIR and strengthened in confirmation of MA Decision No.312K/Sip/1974. However, if it is seen from the doctrine of appropriate forum, the aforementioned decision (MA Decision No.312K/Sip/1974) is a strict law. According to the doctrine of Appropriate Forum if there is connecting factors arise a statement that the case is considered the most appropriate compared with the defendant, then the mediators who the jurisdictions are in the Department of Labor and Transmigration of South Tangerang considered being the authority to conduct proceedings at the mediation level.

The settlement of industrial relations disputes through mediation is expected to be the proceedings which can solve the problems (in this paper is the employment issues related to the expiration of the employment relationship with the PKWT status). The parties are expected to waive their interest to get the results, which altogether give a victory to the party to the fairest. In other words, the results can be accepted by all the parties with the concept of win-win solution. Based on the description above, it is necessary to study the problem formula for this paper is regarding the connectivity factors to instances of industrial disputes related to mediation by the determination of the place of matter or locus delictus as a relative authority. 
If re-assessed to the raise issues, it is necessary to be a reference related to the settlement of disputes of industrial relations in the realm of mediation filed by a party to determine the jurisdiction of which the case occurred. Also, the mediator of industrial relations in the relative authority fullest extent of the jurisdiction to which it aspires to explain the mechanisms related to the presence or absence of the requested authority to the problems. So relate on this, the study would like to explain the concept of positive law and the theory needs to be displayed as an effort to solve the problems as described in the theoretical framework below.

\section{METHODS}

Article uses some positive law approaches related to its title "Mediation in Industrial Relations Dispute and Its Relation with Relative Authority in The Legal Proceedings Process," which consists of several rules as the normative law, such as Law No 2 of 2004, Act Number 30 of 1999, and PERMA No. 1 of 2008.

Law No. 2 of 2004 concern Industrial Relations Dispute Settlement. Several articles used about this paper are: (a) Article 1 Point (11) states "Industrial Relations Mediation that from now on referred as to mediation is the settlement of disputes over rights, conflict over interest, disputes over the termination of the working relationship, and disputes between worker/labor unions within one company only through deliberations that are interceded by one or more mediators who are neutral." (b) Article 8 states "Settlement of a dispute through mediation is carried out by a mediator which present at each Manpower office at the District/City level."

While, Act Number 30 of 1999 on Arbitration and Alternative Dispute Resolution has several points that related to this paper. They are: a) Article 1 point (10) explains that "Alternative dispute resolution means a mechanism for the resolution of disputes or differences of opinion through procedures agreed by the parties, i.e. resolutions outside the courts by consultation, negotiation, mediation, conciliation, or expert assessment.” b) Article 6 point (1) explains that "Disputes or differences of opinion may be resolved by the parties by alternative dispute resolution based on good faith by waiving the resolution by litigation in the District Court.”

And the last, PERMA No. 1 of 2008 on Court Annexed Mediation Procedure also has the points that related to this paper, they are: a) Article 1 point (7) states that "Mediation is a way of resolving disputes through negotiation process to obtain the agreement of the parties with the assistance of a mediator." b) Article 2 point (3) states that "Do not go through mediation procedure is based on this rule is a violation of the provisions of Article 130 HIR and or154 Rbg which resulted in the decision null and void." c) Article 4 states that "Unless the matter is resolved through court procedures commercial, industrial relations court, objected to the decision of Consumer Dispute Settlement Board, and objected to the decision of KPPU, all civil disputes submitted to the Court of First Instance shall first seek the settlement through peace with the help of the mediator."

Meanwhile, the scientific laws are to describe the theories of juris prudence as a positive study to explain social problems (Friedmann, 1944). This is related to the actual link to the positive law in the implementation of dispute settlement of industrial relations as the real implications, especially at the stage of preparation and implementation of the mediation process in the office and the Departement of Manpower and Transmigration related.

To determine the court where the most appropriate, it starts from the fact that the most real and substantial connection with the disputes which is prima facie. In theory and practice, the type or form factor which was considered very relevant connectivity include the following; (1) The 
convenience and expense of litigation; (2) Availability of witnesses and documents; (3) The place where parties reside; (4) The place where to carry on business; (5) The governing laws.

Related to this article raised, there are several related points regarding the prima facie. They are signatories and hiring processes, the event of termination of the contract of employment, worker absenteeism, employment that occurred in the said institutions, the giving and receiving compensation (salary) employees.

There are several ways of dispute resolution in force in Indonesia, namely; (1) Dispute resolution through litigation; (2) Dispute resolution outside the court, which in this paper points out the Alternative Dispute Resolution (ADR) for resolving labor disputes. This is an institution devoted to solving the problem of labor disputes as stipulated in Law No 2 of 2004 concerning Industrial Relations Dispute Settlement. The disputes must first be resolved in mediation before go to the industrial relations court.

Mediation is a way of dispute resolution. Mediation is a problem-solving negotiation process in which third parties, who do not take sides, cooperates with the dispute's parties to get a satisfactory agreement. The mediator only helps the parties to resolve the disputes entrusted to the man do not have the authority to decide the dispute. The reason for the need for ADR is raised because there are many shortcomings and dissatisfaction with the litigation way of dispute resolution, both literal and technical. For the example is the accumulation of cases in the court. Thus, the alternative for dispute resolution is needed (Adolf \& Huala as cited in Nugroho \& SusantiAdi, 2010). Therefore, our challenge, particularly the legal community in Indonesia, is developing the pattern of dispute resolution settlement following the Indonesia values, which is the negotiation for consensus. Law No. 30 of 1999 concerning the arbitration and also emphasize on alternative dispute resolution in mediation and the use of experts. This legislation is an institution of dispute resolution outside the court by agreement of the parties by waiving the dispute resolution through litigation amicably can be taken by the parties to resolve their civil disputes by using institutions negotiation, conciliation, mediation, or expert judgment (Fuady, 2005).

In the era of industrialization, the industrial sector has significantly contributed to national development. However, the many advances in science and technology precisely characterize the presence of this era. It actually makes the problem of industrial relations disputes are becoming increasingly frequent and complex. In the meantime, based on technical considerations and the juridical enactment of Law No 2 of 2004 concerning Industrial Relations Dispute Settlement, which had introduced to the public and declared effective within one year after its enactment on January 14, 2004. The judicial process stages according to the industrial relations legislation was passed by two stages, i.e., outside the court and through industrial relations court. So that the stages are as follows; (1) Resolution through Bipartite, (2) Resolution through Mediation, Conciliation, and Arbitration, (3) Industrial Relations Court in the jurisdiction of the local District Courts.

\section{RESULTS AND DISCUSSIONS}

According to Takdir Rachmadi (2011), factors the parties choose mediation is referring to cultural factors as the dominant factor. Community inherited the tradition of cultural tradition that emphasizes the importance of harmony and togetherness in life. Then this culture to absorb the spiritual values, which are the interests of the actualization of the concept of reconciliation (peace).

Labor disputes as the case study in this article is the case of the termination of the employment contract of two workers in the institutions located in South Tangerang. Then, through their attorney, 
those two workers report the termination of employment to Ministry of Manpower and Transmigration Jakarta. Then, through their attorney those two workers report the termination of employment to Ministry of Manpower and Transmigration Jakarta. However, previously, through their attorney has sent a legal notice to the company to get the answers related to the position and interest of the parties they represent.

Furthermore, by the legal notice received by the company, then the bipartite meeting is held without being written as bipartite meeting result thus deemed not to be a bipartite meeting. This process is an early stage of dispute resolution process of industrial relations, so there must be the minutes of bipartite meeting with the signature of all the parties. The cancellation and failure of the bipartite meeting by the absence of agreement between the dispute parties are the reason of the worker's attorney reported the case to the Department of Manpower in Jakarta to request the mediation process. The tough and intriguing mediation process makes the parties repeat the process of bipartite and make the minutes of the bipartite as formal requirements proceedings following Law No $2 / 2004$. The bipartite still does not meet the agreement, so that the mediation process is reached where the parties have chosen a mediator authoritative local institutions is implemented in accordance with applicable regulations. The mediation process still does not produce an agreement between the parties, so that the mediator is obliged to issue a suggestion related to the mediation process as the final result. This suggestion gives a conclusion that the parties need to record their dispute in the local manpower department (whose jurisdiction in South Tangerang), by enclosing the evidence of the remedies through bipartite negotiations have been conducted. Although, it still open up a rejection related to the suggestion from one of the parties, which cause the industrial relations dispute can proceed to the industrial relations court based on the appeal of one of the parties to the lawsuit by noting the lawsuit numbers to the Office of Industrial Relations Court in Jakarta.

The lawsuit of labor on layoffs disputes that occurred and performed at the Office of Manpower and Transmigration Jakarta is not the authority of local mediator about the relative authority which regulates that the crime scene (locus delictus) outside the jurisdiction of Jakarta. Although the residence of defendant located in the jurisdiction of Jakarta following the principle of Actor sequitur forum Rei. This allowing exceptions filed by the defendant is not in accordance with Article 118 Paragraph (1) HIR, which states that the authority to hear a case is district court in the defendant's residence. As the lawsuit does not cross the relative competence, the lawsuit must be filed and submitted to the District Court based on the territory or jurisdiction where the defendant lives. It is very irrelevant that the application is associated with the suggestionof the Mediator in the Office of Manpower and Transmigration Jakarta to grant an exception made by the company, especially Article 118 Paragraph (1) HIR was reaffirmed by the Supreme Court decision No. 312/Sip/1974. The illustration below attempts to provide an explanation regarding the above principles, as seen in the following figure:

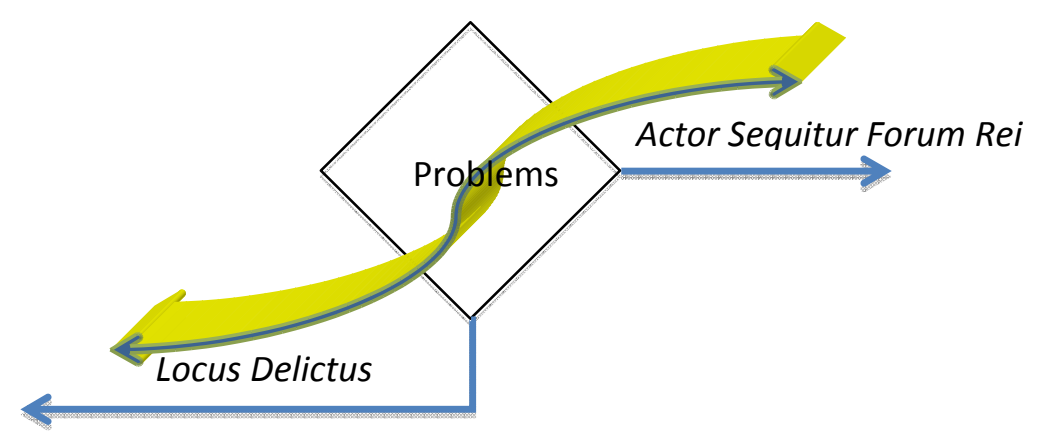

Figure The Principe Actor Sequitur Forum Rei relate Locus Delictus 
The figure represents a case or problem being applied to the mediation of industrial relations. If it can run within the meaning remains the processes are well grounded by the place where the defendant is domiciled (Actor sequitur forum Rei) as well as the scene of the cases (Locus Delictus). It relates into the discussion to their specificity as well as factors related to connectivity, which is considered very close to the issues raised. The recommendation issued by the mediator of the local Office of Manpower with the lex specialist as mentioned in Article 8 of Law No. 2 of 2004, is based on a review of the Doctrine Appropriate forums on the connectivity factors. It can be formulated as follows; (1) The availability of witnesses and documents, (2) The residence of the parties, (3) The place of business activity, (4) Law, (5) The process of signing and recruitment of employment, (6) The employee/worker attendance, (7) The giving and receiving of compensation (salary), (8) The place of teaching and learning process, (9) The renewal and the termination of employement contract makes the relative authority of the Office of Manpower and Transmigration in Jakarta is deemed unfit to carry out the mediation process which is outside the authority. So, the exception of the company may be granted and considered that the Office of Manpower and Transmigration which located at the scene related to the locus delictusis more authorized to have a trial.

The Article 8 of Law No 2 of 2004 as lex specialist used as a basis of reference in issuing a recommendation related to industrial relations disputes, which are described in the Explanation of Law No 2 of 2004 mentioned with quite clear. It can be responded that the article has become a representation of the absence of relative authority by the Office of Manpower and Transmigration Jakarta in handling disputes industrial relations of this paper's subject. So, the delegation of authority is transferred to the Office of Manpower and Transmigration of South Tangerang, which is considered to be more competent in handling this case. If the case ended with peace, then the Mediator at the Office of Man power and Transmigration Jakarta can not issue a Memorandum of Understanding or Actevan Dading, but must convey the matter to the Office of Manpower and Transmigration South Tangerang to do the process. So, under any circumstances, because of the relative authority owned by the Office of Manpower and Transmigration Jakarta. The result of mediation presented in the suggestion is right to avoid the exceeding power of relevant agencies. The previous narration tried to explain that a problem that occurs should pay more attention to the factors of connectivity as a form of specificity and does not become a mean waiver of the issues raised by the Article 118 Paragraph (1) HIR was reaffirmed by the Supreme Court decision No 312/Sip/1974. As shown in the following Table.

Table The Lex Specialist through Subject

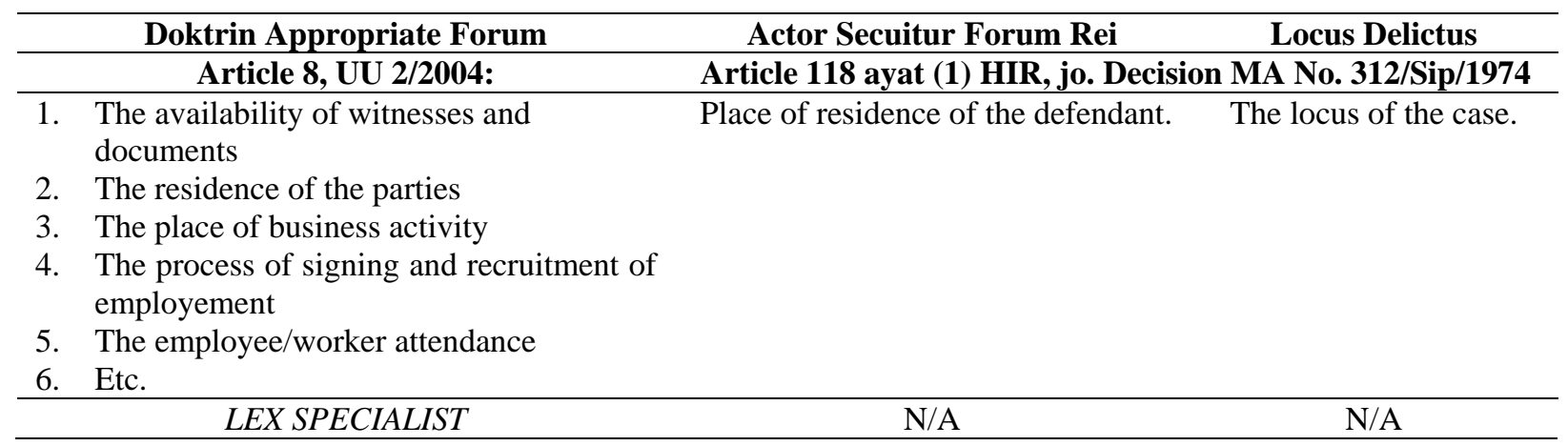

The discussion about the civil lawsuit means discussing the proceedings in civil law by the fulfillment of the formal requirements as the implementation of proceedings for the achievement of formal truth. The non-fulfillment of formal requirements related to the expenditure of suggestion states the accepting of the defendant exception because of the absence of mediator authority in the Office of Manpower and Transmigration Jakarta, which only have relative authority based on the locus delictus 
in the case of worker relation dispute. Based on PERMA No 1 of 2008 related to the mediation process under Article 4 states that all civil disputes shall first seek the settlement through peace with the help of the mediator. There is no exception for the cases that settled through Commercial Court, Industrial Relations court, objection to the decision of Consumer Dispute Settlement Board and objection to the decision of the Business Competition Supervisory Commission (KPPU). This matter is further clarified that the textual legal system in PERMA 1 of 2008 Article 4 is consistent with Law No 2 of 2004. So that, the achievement of the values of legal certainty reflected in the legislation system related to disputes in industrial relations, which are namely the application of the mediation process. Based on a form of Alternative Dispute Resolution (ADR), mediation is categorized as The NonBinding Adjudicative Procedures. It means that the procedure is not binding and purely in the form of the advisory, where a mediator helps the parties reach a settlement by the concept win-win solution in which there are no winners and losers. Thus, the force of law on the recommendation issued by the mediator in the Office of Manpower and Transmigration Jakarta can be interpreted not to have the force of law. In other mediation cases, based on writer's knowledge, if the mediation process reaches an agreement and set in the Settlement Deed or an Agreement or Treaty Agreements, in order to have binding legal force, the mediator or one of the parties must submit an application as the lawsuit to district court to have the determination. So with the determination, the party that has the breach of contract will be confronted with new problems in the sphere of civil law or criminal law. Without the legal power related to mediator's recommendation issued by the Office of Manpower and Transmigration of Jakarta, it can be possible if the parties reject the results of these recommendations then to appeal a lawsuit against the industrial relations court at the same jurisdiction.

\section{CONCLUSIONS}

Mediation on industrial relations dispute is civil problems that are constituted by Act No 2 of 2004. It consists of disputes over rights, conflict over interest, termination of employment disputes, and disputes between trade unions within one company. Related to this study, the industrial dispute that happened is the dispute layoffs which raises the demands related to the rights of workers who considered that the employment contract is null and void. It because of Article 59 paragraph (1) and (2) Law No 13 of 2003 on Labour, which explains that the work as the core business can not be done PKWT does not comply. The dispute resolution is made in the mediation process at the Office of Manpower and Transmigration of Jakarta on the results of the recommendation made by the authorities in these institutions that based on the positive law as the lex specialist, namely Article 8 of Law No 2 of 2004 on provisions HIR and regulated in the Indonesian Criminal Procedure Code. So, it seems right when added with Doctrine of Appropriate Forum which explained the connectivity related with industrial relations disputes in this paper. Therefore, the consideration of the determination of the relative authority by Mediator at the Office of Manpower and Transmigration Jakarta becomes nothing and should be brought to the jurisdiction of the disputed scene (locus delictus).

The emergence of a dispute or disagreement in all aspects of community life is something that needs to be avoided. Based on the human nature, we are as social beings need to have understanding and application following the law as a means of regulating ways of life and interactions with other. Conflict of industrial relations dispute is one of the social problems, where there is a certain idealism to the application and interpretation of positive law, so the differences of interest between the parties are emerging. Problems of industrial relations dispute need to be examined more fundamentally by conscience and principle of unity in achieving a common goal, so that the conflict between the warring parties and resolved with the equal position between the parties.

Unfortunately, the things that have been mentioned above simply be an expression and theories, where similar cases need more attention and awareness of the relevant parties in a 
comprehensive manner. If the proceedings problem in this writing is related to mediation, then the interests of the parties should disregard the positive law as the jurisprudence. Therefore, it means the related mediator can carry out its functions without the need to include rules as norms and principle that in the end did not meet the expected goals as it is the end of the industrial relations dispute with a win-win solution.

\section{REFERENCES}

Adi, S., Nugroho. (2010). Class Action dan Perbandingannya dengan Negara Lain. Surabaya: Kencana.

Friedmann, W. (1944). Legal Theory. London: Steven \& Sons Limited.

Fuady, M. (2005). Pengantar Hukum Bisnis. Bandung: Citra Aditya Bakti.

Harahap, \& Yahya, M. (2008). Hukum Acara Perdata. Jakarta: Sinar Grafika.

Nugroho, \& Adi, S. (2009). Mediasi Sebagai Alternatif Penyelesaian Sengketa. Jakarta: Telaga Ilmu Indonesia.

Sari, Elsi, K., \& Simanunsong, A. (2008). Hukum dalam Ekonomi. Jakarta: Gramedia.

Soeroso, R. (2006). Pengantar Ilmu Hukum. Jakarta: Sinar Grafika.

Rahmadi, T. (2010). Mediasi: Penye lesaian sengketa melalui pendekatan mufakat. Jakarta: PT Raja Grafindo Persada. 